Bangladesh J. Sci. Ind. Res. 42(3), 299-310, 2007

\title{
Change in Some Chemical Parameters of two Environment Polluting Waste (Fertilizer Factory Effluent and Sweetmeat Factory Waste) Media After Culture of Three Important Microalgae
}

\author{
M.A. Toyub,* M.I. Miah and M.A.B. Habib \\ Bangladesh Agricultural University, Mymensingh-2202, Bangladesh
}

\begin{abstract}
Some chemical parameters of fertilizer factory effluent (FFE) and sweetmeat factory waste (SFW) were analyzed before and after culture of three important microalgae (Spirulina platensis, Chlorella ellipsoidea and Scenedesmus obliquus) to make the waste environment friendly and to develop their economic use. Among the two wastes significantly $(\mathrm{P}<0.05)$ higher phosphate phosphorus $(116.09 \mathrm{mg} / \mathrm{l})$, ammonia nitrogen (17.39), total suspended solids (TDS, $949.00 \mathrm{mg} / \mathrm{l}$ ), total dissolved solids (28924.67 mg/l), total solids (30009.00 mg/l) and chemical oxygen demand (7892.00 $\mathrm{mg} / \mathrm{l})$ were in raw SFW. On the other hand significantly higher $\mathrm{pH}$ (7.51), nitrite nitrogen (19.65) and dissolved oxygen (0.33) were significantly higher in collected raw FFE. Before culture of $S$. platensis TDS of the prepared media were very high (10200.00 mg/l) due to addition of $\mathrm{NaHCO}_{3}$. Before inoculation of C. ellipsoidea and S. obliquus the highest TS, TSS, TDS and COD were recorded 867.28, 49.67, 771.33 and $1424.33 \mathrm{mg} / \mathrm{l}$, respectively in prepared media. But after the culture of all the three microalgae, the amount of TS, TSS, TDS and COD were significantly $(\mathrm{P}<0.05)$ lower in all the media. The cultured microalgae were nutritionally rich.
\end{abstract}

Key words : Chemical parameters, fertilizer factory effluent, sweetmeat factory waste, microalgae.

\section{Introduction}

Bangladesh is an agro-based country. The agro-industrial organic wastes discharged from different types of mill containing high organic and inorganic nutrients, high total dissolved solids due to high carbohydrate and micronutrient which increase both biological oxygen demand (BOD) and chemical oxygen demand (COD) in aquatic environment

* Corresponding Author
(Phang, 1990 and Habib et al., 1998). The organic loads as well as COD are possible to reduce by aerobic and anaerobic digestion of the waste discharge and growing important (beneficial) microalgae (Phang, 1990 and Husain, 2001). The highest COD value 500980 ppm with either aerobic or anaerobic digestion is not harmful for aquaculture (Phang, 1990). 
In Bangladesh five big fertilizer factories are discharging huge amount of inorganic effluent in nature every year, which polluted aquatic environment. A large number of sweet meat factories have been developed both urban and rural area of Bangladesh, which discharge a lot amount of wastes in aquatic environment. Ultimately all of these wastes cause partial environmental pollution, which may causes partial ecological imbalance in nature and increase both biological oxygen demand (BOD) and chemical oxygen demand (COD) in aquatic environment. Sweetmeat factory waste (SFW) and Fertilizer factory effluent (FFE) are discharging through out the year. The economic uses of these wastes are not yet been developed. However, these wastes are possible to use for the production of microalgae having some modification. In aquaculture system, these wastes might be used to produce commercially important microalgae, which may use as feed for fish fry/fingerlings, shrimp larvae as well as zooplankton in aquaculture system. Due to microalgal activity, harmful and polluting affects of the wastes will be reduced after culture of microalgae and thus the environment will be free from pollution partially. So, it is essential to study the chemical characteristics of these environment polluting wastes before and after culture of microalgae. Keeping this in mind, attempt was made to study the chemical characteristics of sweetmeat factory waste and fertilizer factories effluent before and after culture of three important micoalgae, Chlorella ellipsoidea, Spirulina platensis and Scenedesmus obliquus.

\section{Materials and Methods}

Two environment polluting waste, fertilizer factory effluent (FFE) and sweetmeat factory waste (SFW), and three important microalgae, Chlorella ellipsoidea, Spirulina platensis and Scenedesmus obliquus were used in this study.

\section{Collection and preparation of fertilizer factory effluent (FFE) medium}

Fertilizer factory effluent was collected from Jamuna Fertilizer Factory, Tarakanda, Jamalpur and it was decomposed for a period of 15 days by aeration. It should be noted that before collection, chemical treatment of effluents by $\mathrm{H}_{2} \mathrm{SO}_{4}$ and $\mathrm{Al}_{2}\left(\mathrm{SO}_{4}\right)_{3} \cdot \mathrm{K}_{2} \mathrm{SO}_{4}$. $24 \mathrm{H}_{2} \mathrm{O}$ and partial water treatment by flashing and circulating water was done by the factory authirity. However, the decomposed solution was filtered and diluted with distilled water to 40, 45, 50, 55 and $60 \%$ concentration levels. For culture of S. platensis $6.0 \mathrm{~g} / \mathrm{l} \mathrm{NaHCO}_{3}$ was added to increase $\mathrm{pH}$ level of the media.

\section{Collection and preparation of sweetmeat factory waste (SFW) medium}

Sweetmeat waste was collected from Mymensingh town. It was diluted with distilled water to 1.5, 2.0, 2.5 and $3.0 \%$ concentration levels and was decomposed for a period of 30 days by aeration at room temperature. The supernatant of decomposed effluent was for algal culture. Urea $(0.2 \mathrm{~g} / \mathrm{l})$ was added to the media to increase nitrogen 
content for culture of all the three algal species. On the other hand $\mathrm{NaHCO}_{3}(6.0 \mathrm{~g} / \mathrm{l})$ was added to the media to increase $\mathrm{pH}$ level, only for spirulina culture.

\section{Chemical analysis of raw waste sample}

To know the chemical status of collected raw waste sample of FFE and SFW, different chemical parameters such as $\mathrm{pH}$, dissolved oxygen (DO), chemical oxygen demand
(COD), total solids (TS), total suspended solids (TSS), total dissolved solids (TDS), phosphate phosphorus $\left(\mathrm{PO}_{4}-\mathrm{P}\right)$, nitrate nitrogen $\left(\mathrm{NO}_{3}-\mathrm{N}\right)$, nitrite nitrogen $\left(\mathrm{NO}_{2}-\mathrm{N}\right)$ and ammonia nitrogen $\left(\mathrm{NH}_{3}-\mathrm{N}\right)$ were analyzed before decomposition.

Prepared FFE and SFW media were sterilized at $120^{\circ} \mathrm{C}$ for 15 minutes with moist heat autoclave (Express Equipment, Dixon's surgical instrument LTD).

Table I. Composition of bold basal medium (BBM) for Chlorella ellipsoidea and Scenedesmus obliquus culture

\begin{tabular}{|c|c|c|c|}
\hline SI. No. & Chemicals/ compounds & $\begin{array}{c}\text { Concentration in stock } \\
\text { solution }(\mathrm{g} / \mathrm{l})\end{array}$ & $\begin{array}{l}\text { Amount in culture } \\
\text { medium }(\mathrm{ml} / \mathrm{l})\end{array}$ \\
\hline 1. & $\mathrm{NaNO}_{3}$ & 25.00 & 10.0 \\
\hline 2. & $\mathrm{MgSO}_{4} \cdot 7 \mathrm{H}_{2} \mathrm{O}$ & 7.50 & 10.0 \\
\hline 3. & $\mathrm{NaCI}$ & 2.50 & 10.0 \\
\hline 4. & $\mathrm{~K}_{2} \mathrm{HPO}_{4}$ & 7.50 & 10.0 \\
\hline 5. & $\mathrm{KH}_{2} \mathrm{PO}_{4}$ & 17.50 & 10.0 \\
\hline 6. & $\mathrm{CaCl}_{2} \cdot 2 \mathrm{H}_{2} \mathrm{O}$ & 2.50 & 10.0 \\
\hline \multirow[t]{6}{*}{7.} & Trace element & & 1.0 \\
\hline & a) $\mathrm{ZnSO}_{4} \cdot 7 \mathrm{H}_{2} \mathrm{O}$ & 8.82 & \\
\hline & b) $\mathrm{MnCl}_{2} \cdot 4 \mathrm{H}_{2} \mathrm{O}$ & 1.44 & \\
\hline & c) $\mathrm{MoO}_{3}$ & 0.71 & \\
\hline & d) $\mathrm{CuSO}_{4} \cdot 5 \mathrm{H}_{2} \mathrm{O}$ & 1.57 & \\
\hline & e) $\mathrm{Co}\left(\mathrm{NO}_{3}\right)_{2} \cdot 6 \mathrm{H}_{2} \mathrm{O}$ & 0.94 & \\
\hline 8. & $\mathrm{H}_{3} \mathrm{BO}_{3}$ & 11.40 & 1.0 \\
\hline \multirow[t]{3}{*}{9.} & EDTA-KOH solution & & 1.0 \\
\hline & a) EDTA $\mathrm{Na}_{2}$ & & \\
\hline & b) $\mathrm{KOH}$ & 50.00 & 1.0 \\
\hline \multirow[t]{2}{*}{10.} & a) $\mathrm{FeSO}_{4} \cdot 7 \mathrm{H}_{2} \mathrm{O}$ & 31.00 & \\
\hline & b) Conc. $\mathrm{H}_{2} \mathrm{SO}_{4}$ & $4.981 .0 \mathrm{ml} / \mathrm{l}$ & 1.0 \\
\hline
\end{tabular}

- Was made up to 1 litre with distilled water and

- $\quad$ Autoclaved at $126^{\circ} \mathrm{C}$ for 15 minutes 


\section{Preparation of control media}

Bold Basal Medium (BBM) and Kosaric Medium (KM) were used as the inorganic media. Different composition of inorganic nutrients of BBM, Phang and Chu (1999) is given in Table I. And different composition of inorganic nutrients of Kosaric Medium (KM), modified form of Zarouk (1966), and Phang and Chu (1999) is given in Table II.

Table II. Different composition of inorganic nutrients of Kosaric Medium (KM) for Spirulina platensis culture

\begin{tabular}{c|l|c}
\hline SI. No. & Chemicals & Amount (g/l) \\
\hline 1. & $\mathrm{NaHCO}_{3}$ & 9.00 \\
2. & $\mathrm{~K}_{3} \mathrm{HPO}_{4}$ & 0.25 \\
3. & $\mathrm{NaNO}_{3}$ & 1.25 \\
4. & $\mathrm{~K}_{2} \mathrm{SPO}_{4}$ & 0.50 \\
5. & $\mathrm{NaCl}$ & 0.50 \\
6. & $\mathrm{MgSO}_{4}$ & 0.10 \\
7. & $\mathrm{CaCl}_{2}$ & 0.02 \\
8. & $\mathrm{FeSO}_{4}, 2 \mathrm{H}_{2} \mathrm{O}$ & 0.005 \\
9. & & \\
& $\mathrm{As} \mathrm{micronutrient} \mathrm{solution}^{\mathrm{a}}$ & $0.50 \mathrm{ml} / \mathrm{l}$ \\
& a) $\mathrm{As} \mathrm{micronutrient} \mathrm{solution}$ & $(\mathrm{g} / \mathrm{l})$ \\
& $\mathrm{H}_{3} \mathrm{BO}_{3}$ & 2.86 \\
& $\mathrm{MnCl}_{2}, 4 \mathrm{H}_{2} \mathrm{O}$ & 1.81 \\
& $\mathrm{ZnSO}_{4}, 7 \mathrm{H}_{2} \mathrm{O}$ & 0.22 \\
& $\mathrm{CuSO}_{4}, 5 \mathrm{H}_{2} \mathrm{O}$ & 0.08 \\
& $\mathrm{MoO}_{3}$ & 0.01 \\
& $\mathrm{CoCl}_{2}, 6 \mathrm{H}_{2} \mathrm{O}$ & 0.01 \\
\hline
\end{tabular}

- Was made up to 1 litre with distilled water and - Autoclaved at $126^{\mathrm{O}} \mathrm{C}$ for 15 minutes

\section{Culture of microalgae}

Stock culture of S. platensis, C. ellipsoidea and $S$. obliquus maintained in the Department of Aquaculture, Bangladesh Agricultural University, Mymensingh, Bangladesh was used for this study. The microalgae were inoculated into each 1.0 liter volumetric culture flask from the stock (optical density 620nm=0.20, Habib, et. al., 1998) to get $10 \%$ suspension of algae in different culture media including control. As control kosaric medium (KM) was used for S. platensis culture and bold basal medium (BBM) for C. ellipsoidea and $S$. obliquus culture. Three replications were used both for culture and control media. All the flasks were kept under fluorescent lights (light: dark $=12$ h: 12 h) for 14 days in Live Food Culture Laboratory of the Department of Aquaculture, Bangladesh Agricultural University, Mymensingh, Bangladesh. The culture flasks were continuously aerated using electric aerator. All the glass-wares used in the experiment were sterilized with dry heat in an oven at $70^{\circ} \mathrm{C}$ for 12 hrs. Growth parameters of algae viz., cell counts and Chlorophyll a content were recorded every alternate day using a compound microscope and UV spectrophotometer, respectively. After successful completion of laboratory culture, the algae were centrifuged at $3000 \mathrm{rpm}$ for 10 minutes to separate the media from microalgae from each other. The chemical properties of separated media were analyzed. After completion of laboratory culture mass culture was per- 
formed in better concentrations (50 \% FFE and $2.5 \%$ SFWM) of the media. During mass culture microalga was harvested before stationary phase and centrifuged at $3000 \mathrm{rpm}$ for 10 minutes to separate the microalga. The separated microalgae were used for proximate composition analysis.

Before inoculation of microalgae (C. ellipsoidea, S. platensis and S. obliquus) in different concentrations of culture media prepared by FFE and SFW, and control medium (BBM and KM), sub samples were collected. Chemical properties such as $\mathrm{pH}$ dissolved oxygen (DO), chemical oxygen demand (COD), total solids (TS), total suspended solids (TSS) and total dissolved solids (TDS) of the collected sub samples were analyzed following standard methods (Clesceri et al., 1989). After laboratory culture, same chemical parameters of the separated media were analyzed.

\section{Results and Discussion}

Chemical composition of collected raw FFE and SFW showed that significantly $(\mathrm{p}<0.01)$ higher $\mathrm{pH}, \mathrm{NO}_{2}-\mathrm{N}$ and $\mathrm{DO}$ was in FFE. On the other hand significantly $(\mathrm{p}<0.01)$ higher amount of $\mathrm{PO}_{4}-\mathrm{P}, \mathrm{NH}-\mathrm{N}$, TSS, TS and COD was in SFW. Nitrite nitrogen was $29.73 \mathrm{mg} / \mathrm{l}$ in FFE and $30.05 \mathrm{mg} / \mathrm{l}$ in SFW. The whole results are shown in the Table III. The physico-chemical analysis of the two effluents under the present study indicates that the media are nutrient rich. In a study Wing and Chong (2002) analyzed the chemical composition of palm kernel meal, which is more or less agrees with the present findings. Habib et al. (1998) determine the chemical contents of raw latex concentrate rubber effluent, standard Malaysian rubber effluent and palm oil mill effluent which is not similar with the present findings. It may be due to the different source of effluents.

Table III. Mean ( \pm SD) chemical composition (mg/l, except pH) of collected raw FFE and SFW sample before decomposition

\begin{tabular}{l|l|l}
\hline Composition & FFE & SFW \\
\hline $\mathrm{pH}$ & $7.51 \pm 0.04^{\mathrm{a}}$ & $4.92 \pm 0.04^{\mathrm{b}}$ \\
Phosphate phosphorus $\left(\mathrm{PO}_{4}-\mathrm{P}\right)$ & $11.62 \pm 0.28^{\mathrm{b}}$ & $116.09 \pm 2.01^{\mathrm{a}}$ \\
Nitrate nitrogen $\left(\mathrm{NO}_{3}-\mathrm{N}\right)$ & $29.73 \pm 0.40^{\mathrm{a}}$ & $30.05 \pm 0.62^{\mathrm{a}}$ \\
Nitrite nitrogen $\left(\mathrm{NO}_{2}-\mathrm{N}\right)$ & $19.65 \pm 0.09^{\mathrm{a}}$ & $1.54 \pm 0.27^{\mathrm{b}}$ \\
Ammonia nitrogen (NH & $17.39 \pm 0.61^{\mathrm{a}}$ \\
Total suspended solid (TSS) & $12.46 \pm 0.22^{\mathrm{b}}$ & $949.00 \pm 30.61^{\mathrm{a}}$ \\
Total dissolved solid (TDS) & $37.00 \pm 1.00^{\mathrm{b}}$ & $28924.67 \pm 53.53^{\mathrm{a}}$ \\
Total solid (TS) & $785.00 \pm 3.61^{\mathrm{b}}$ & $30009.00 \pm 102.66^{\mathrm{a}}$ \\
Dissolved oxygen (DO) & $838.33 \pm 4.04^{\mathrm{b}}$ & $0.00 \pm 0.00^{\mathrm{b}}$ \\
Chemical oxygen demand (COD) & $0.33 \pm 0.06^{\mathrm{a}}$ & $7892.00 \pm 75.50^{\mathrm{a}}$ \\
\hline
\end{tabular}

Data in a row followed by different letter (s) indicate significant differences at 5 \% level 
The highest growth of the cultured algae was observed on the 10 th day of culture in both media. The growth performance of the cultured microalgae is shown in Table IV. Among the different concentrations of the
$6336.00 \mathrm{mg} / \mathrm{l}$ in $40 \%$ FFEM. The range of TSS and was recorded 11.15 to $42.33 \mathrm{mg} / \mathrm{l}$ and the highest value was recorded in $3.0 \%$ SFWM and the lowest value was recorded in KM. The highest TDS was recorded

Table IV. Growth performance of S. platensis, $C$. ellipsoidea and $S$. obliquus in different concentrations of waste media at 10th day of culture

\begin{tabular}{l|c|c|c|c|c|c}
\hline \multirow{2}{*}{ Media } & \multicolumn{2}{|c|}{ S. platensis } & \multicolumn{2}{c|}{ C. ellipsoidea } & \multicolumn{2}{c}{ S. obliquus } \\
\cline { 2 - 7 } & $\begin{array}{c}\text { Cell wt. mg/l } \\
(\mathrm{mg} / \mathrm{l})\end{array}$ & $\begin{array}{c}\text { Chlorophyll } a \\
(\mathrm{mg} / \mathrm{l})\end{array}$ & $\begin{array}{c}\text { Cell no. } \\
\left(\mathrm{x} 10^{5}\right) / \mathrm{ml}\end{array}$ & $\begin{array}{c}\text { Chlorphyll } a \\
(\mathrm{mg} / \mathrm{l})\end{array}$ & $\begin{array}{c}\text { Cell no. } \\
\left(\mathrm{x} 10^{5}\right) / \mathrm{ml}\end{array}$ & $\begin{array}{c}\text { Chlorophyll } a \\
(\mathrm{mg} / \mathrm{l})\end{array}$ \\
\hline $40 \%$ FFEM & $622.67 \pm 9.50$ & $5.36 \pm 0.12$ & $121.37 \pm 4.08$ & $5.85 \pm 0.44$ & $82.37 \pm 5.00$ & $4.63 \pm 0.41$ \\
$45 \%$ FFEM & $715.33 \pm 9.46$ & $6.47 \pm 0.16$ & $142.34 \pm 5.91$ & $7.29 \pm 0.29$ & $87.71 \pm 5.64$ & $5.11 \pm 0.30$ \\
$50 \%$ FFEM & $846.67 \pm 9.02$ & $7.52 \pm 0.13$ & $182.07 \pm 9.70$ & $8.08 \pm 0.29$ & $119.10 \pm 6.03$ & $6.12 \pm 0.39$ \\
$55 \%$ FFEM & $803.33 \pm 12.06$ & $7.17 \pm 0.25$ & $157.41 \pm 6.02$ & $7.06 \pm 0.20$ & $93.49 \pm 5.81$ & $5.42 \pm 0.25$ \\
$60 \%$ FFEM & $692.67 \pm 16.8$ & $6.29 \pm 0.30$ & $137.57 \pm 6.86$ & $6.55 \pm 0.32$ & $99.33 \pm 6.60$ & $5.62 \pm 0.32$ \\
KM/BBM & $916.00 \pm 22.07$ & $7.96 \pm 0.30$ & $198.49 \pm 6.05$ & $9.39 \pm 0.31$ & $135.34 \pm 7.92$ & $6.86 \pm 0.31$ \\
$1.5 \%$ SFWM & $448.33 \pm 4.16$ & $4.16 \pm 0.28$ & $75.21 \pm 4.96$ & $4.22 \pm 0.36$ & $51.21 \pm 5.88$ & $2.71 \pm 0.28$ \\
$2.0 \%$ SFWM & $546.00 \pm 6.24$ & $4.87 \pm 0.26$ & $98.50 \pm 3.70$ & $5.33 \pm 0.43$ & $65.19 \pm 7.09$ & $3.61 \pm 0.31$ \\
$2.5 \%$ SFWM & $705.00 \pm 8.72$ & $6.73 \pm 0.23$ & $141.80 \pm 7.15$ & $7.47 \pm 0.44$ & $97.05 \pm 7.01$ & $5.52 \pm 0.41$ \\
$3.0 \%$ SFWM & $619.33 \pm 8.08$ & $5.41 \pm 0.30$ & $110.48 \pm 7.99$ & $5.82 \pm 0.30$ & $83.21 \pm 4.97$ & $4.77 \pm 0.29$ \\
KM/BBM & $933.67 \pm 9.61$ & $8.58 \pm 0.28$ & $181.54 \pm 9.13$ & $9.28 \pm 0.38$ & $136.30 \pm 9.00$ & $6.14 \pm 0.36$ \\
\hline
\end{tabular}

media $50 \%$ FFEM and $2.5 \%$ SFWM showed better growth performance than other concentrations for all the three microalgae. On the other hand among these two, 50\% FFEM showed the best growth performance for all the three species. Proximate composition showed that the cultured algae were nutritionally rich having 34.56 to $58.38 \%$ protein (Table V).

In the case of before culture of S. platensis, the highest average TS was recorded $10216.97 \mathrm{mg} / \mathrm{l}$ in $\mathrm{KM}$ and the lowest was
$10200.00 \mathrm{mg} / \mathrm{l}$ in $\mathrm{KM}$ and the lowest TDS was observed $6311.0 \mathrm{mg} / \mathrm{l}$ in $40 \%$ FFEM. For the culture of $S$. platensis, media were prepared adding $6 \mathrm{mg} / \mathrm{l} \mathrm{NaHCO}_{3}$ in each concentration of waste media and for KM it was needed $9 \mathrm{mg} / \mathrm{l}$. That is why more solids were observed in $\mathrm{KM}$ and comparatively higher solid were recorded before inoculation in both media. The range of $\mathrm{pH}$ and $\mathrm{DO}$ were recorded 8.50 (in $\mathrm{KM}$ ) to $8.67 \mathrm{mg} / \mathrm{l}$ (in $45 \%$ FFEM), and 3.20 (in $55 \%$ FFEM) to 3.77 $\mathrm{mg} / \mathrm{l}$ (in $0.50 \mathrm{~g} / \mathrm{l} \mathrm{KM}$ ), respectively. The 
Table V. Proximate composition of S. platensis, C. ellipsoidea and C. ellipsoidea grown in $50 \%$ FFEM and $2.5 \%$ SFWM

\begin{tabular}{l|c|c|c|c|c|c}
\hline \multirow{2}{*}{ Composition } & \multicolumn{2}{|c|}{ S. platensis } & \multicolumn{2}{c|}{ C. ellipsoidea } & \multicolumn{2}{c}{ S. obliquus } \\
\cline { 2 - 7 } & $50 \%$ & $2.5 \%$ FWM & $50 \%$ & $2.5 \%$ FWM & $50 \%$ & $25 \%$ \\
& FFEM & & FFEM & & FFEM & SFWM \\
\hline Crude protein & $58.38 \pm$ & $55.13 \pm 0.86^{\mathrm{b}}$ & $44.63 \pm 0.11^{\mathrm{c}}$ & $42.45 \pm 1.16^{\mathrm{c}}$ & $37.21 \pm$ & $34.56 \pm$ \\
& $0.37^{\mathrm{a}}$ & & & & $0.14^{\mathrm{d}}$ & $1.12^{\mathrm{d}}$ \\
Crude lipid & $11.41 \pm$ & $13.74 \pm$ & $11.15 \pm 0.06^{\mathrm{d}}$ & $11.15 \pm 0.61^{\mathrm{d}}$ & $17.37 \pm$ & $16.13 \pm 0.85^{\mathrm{ab}}$ \\
& $1.00^{\mathrm{d}}$ & $0.53^{\mathrm{c}}$ & & & $0.08^{\mathrm{a}}$ & \\
Ash & $7.33 \pm$ & $8.66 \pm$ & $10.49 \pm 0.53^{\mathrm{c}}$ & $12.24 \pm 0.85^{\mathrm{b}}$ & $14.20 \pm$ & $12.08 \pm 0.36^{\mathrm{b}}$ \\
Crude fiber & $0.17^{\mathrm{d}}$ & $0.63^{\mathrm{d}}$ & & & $0.13^{\mathrm{a}}$ & \\
& $6.71 \pm$ & $7.71 \pm 0.42^{\mathrm{a}}$ & $5.26 \pm$ & $7.55 \pm$ & $7.46 \pm$ & $6.39 \pm 0.18^{\mathrm{b}}$ \\
Moisture & $0.42^{\mathrm{b}}$ & & $0.03^{\mathrm{c}}$ & $0.38^{\mathrm{a}}$ & $0.21^{\mathrm{a}}$ & \\
& $7.62 \pm$ & $8.29 \pm 0.47^{\mathrm{b}}$ & $9.73 \pm$ & $9.48 \pm$ & $9.54 \pm$ & $8.81 \pm 0.31^{\mathrm{b}}$ \\
NFE & $0.44^{\mathrm{c}}$ & & $0.11^{\mathrm{a}}$ & $0.38^{\mathrm{a}}$ & $0.15^{\mathrm{a}}$ & \\
& $8.76 \pm$ & $6.46 \pm 0.22^{\mathrm{e}}$ & $18.23 \pm 0.28^{\mathrm{b}}$ & $17.34 \pm 0.81^{\mathrm{bc}}$ & $14.23 \pm 0.28^{\mathrm{c}}$ & $22.36 \pm 0.79^{\mathrm{a}}$ \\
\hline
\end{tabular}

Data in a row followed by different letter (s) indicate significant differences at $5 \%$ level

highest average COD was recorded $1899.00 \quad 1163.67 \mathrm{mg} / \mathrm{l}$ in $1.5 \%$ SFWM. The results are $\mathrm{mg} / \mathrm{l}$ in $60 \%$ FFEM and the lowest COD was shown in the Table VI.

Table VI. Mean ( \pm SD) Chemical contents (mg/l, except $\mathrm{pH}$ ) determined in different concentration of FFEM and SFWM KM media before inoculation of $S$. platensis

\begin{tabular}{l|c|c|c|c|c|c}
\hline Media & $\mathrm{pH}$ & DO & TS & TSS & TDS & COD \\
\hline $40 \%$ FFEM & $8.54 \pm 0.05$ & $3.37 \pm 0.21$ & $6336.00 \pm 4.58$ & $22.00 \pm 1.00$ & $6311.00 \pm 4.00$ & $1312.00 \pm 14.42$ \\
$45 \%$ FFEM & $8.56 \pm 0.02$ & $3.43 \pm 0.15$ & $6371.00 \pm 5.57$ & $24.00 \pm 1.00$ & $6344.00 \pm 4.58$ & $1444.67 \pm 7.02$ \\
$50 \%$ FFEM & $8.50 \pm 0.16$ & $3.27 \pm 0.21$ & $6421.67 \pm 9.07$ & $26.33 \pm 0.58$ & $6391.67 \pm 6.66$ & $1598.00 \pm 12.49$ \\
$55 \%$ FFEM & $8.52 \pm 0.02$ & $3.20 \pm 0.20$ & $6466.00 \pm 7.81$ & $31.00 \pm 1.00$ & $6432.00 \pm 5.29$ & $1753.33 \pm 8.74$ \\
$60 \%$ FFEM & $8.50 \pm 0.02$ & $3.33 \pm 0.15$ & $6512.00 \pm 5.00$ & $34.33 \pm 0.58$ & $6475.33 \pm 5.03$ & $1899.00 \pm 11.79$ \\
$1.5 \%$ SFWM & $8.62 \pm 0.06$ & $3.47 \pm 0.5$ & $6545.33 \pm 6.09$ & $23.33 \pm 1.15$ & $6519.00 \pm 3.61$ & $1163.67 \pm 8.62$ \\
$2.0 \%$ SFWM & $8.57 \pm 0.09$ & $3.47 \pm 0.12$ & $6652.00 \pm 8.89$ & $26.33 \pm 1.53$ & $6613.33 \pm 4.04$ & $1279.00 \pm 7.00$ \\
$2.5 \%$ SFWM & $8.59 \pm 0.04$ & $3.50 \pm 0.20$ & $6746.33 \pm 8.02$ & $38.00 \pm 1.00$ & $6702.67 \pm 6.11$ & $1364.33 \pm 8.50$ \\
$3.0 \%$ SFWM & $8.57 \pm 0.09$ & $3.40 \pm 0.17$ & $6849.67 \pm 6.03$ & $42.33 \pm 0.58$ & $6795.33 \pm 4.04$ & $1483.00 \pm 8.19$ \\
KM & $8.67 \pm 0.03$ & $3.50 \pm 0.10$ & $10216.97 \pm 8.70$ & $11.15 \pm 0.92$ & $10200.00 \pm 8.44$ & \\
\hline
\end{tabular}


After the culture of S. platensis the highest TS was recorded $1515.67 \mathrm{mg} / \mathrm{l}$ in $60 \%$ FFEM and the lowest TS was recorded $967.73 \mathrm{mg} / \mathrm{l}$ in KM. On the other hand, the range of TSS and TDS were found 7.67 (in $\mathrm{KM}$ ) to $38.00 \mathrm{mg} / \mathrm{l}$ (in $3.0 \% \mathrm{SFWM}$ ) and 957.24 (in KM) to $1523.67 \mathrm{mg} / \mathrm{l}$ (in $3.0 \%$ SFWM), respectively. The range of $\mathrm{pH}$ and DO were recorded 7.62 (in $45 \%$ FFEM) to 8.17 (in KM) and 2.70 (in 2.0\% SFWM) to $2.93 \mathrm{mg} / \mathrm{l}$ (in $2.5 \% \mathrm{SFWM}$ ), respectively. The highest average COD was recorded $438.33 \mathrm{mg} / \mathrm{l}$ in $60 \%$ FFEM and the lowest COD was recorded $249.33 \mathrm{mg} / \mathrm{l}$ in $40 \%$ FFEM. The findings are presented in the Table VII. After the culture of S. platensis, the solids like TS, TSS, TDS and COD were found significantly $(\mathrm{P}<0.05)$ lower. Here both organic and inorganic loads were mixed the study of Habib et al. (1997) where they studied with palm oil mill effluent in Malaysia.

In case of before culture of $C$. ellipsoidea and S. obliquus the range of average $\mathrm{pH}$ and $\mathrm{DO}$ was observed 7.03 to 7.13 and 2.77 to 3.37 $\mathrm{mg} / \mathrm{l}$, respectively, in different concentration of media including BBM. The highest average TS was observed $867.28 \mathrm{mg} / \mathrm{l}$ in $\mathrm{BBM}$ and the lowest was $332.59 \mathrm{mg} / \mathrm{l}$ in $40 \%$ FFEM. The range of TSS was found 2.88 (in $\mathrm{BBM}$ ) to $22.33 \mathrm{mg} / \mathrm{l}$ (in $3.0 \% \mathrm{SFWM}$ ). The highest TDS was recorded $861.04 \mathrm{mg} / \mathrm{l}$ in $\mathrm{BBM}$ and the lowest was $316.48 \mathrm{mg} / \mathrm{l}$ in 40 $\%$ FFEM. The average highest COD was recorded $1238.0 \mathrm{mg} / \mathrm{l}$ in $3.0 \% \mathrm{SFWM}$ and the lowest was $916.33 \mathrm{mg} / \mathrm{l}$ in $40 \%$ FFEM. The findings of the present study are shown in the Table VIII.

Table VII. Mean ( \pm SD) Chemical contents (mg/l, except $\mathrm{pH}$ ) determined in different concentration of FFEM, SFWM and KM media after culture of $S$. platensis

\begin{tabular}{l|c|c|c|c|c|c}
\hline Media & $\mathrm{pH}$ & $\mathrm{DO}$ & $\mathrm{TS}$ & \multicolumn{1}{c|}{ TSS } & TDS & COD \\
\hline $40 \%$ FFEM & $7.74 \pm 0.05$ & $2.90 \pm 0.10$ & $1377.67 \pm 6.66$ & $15.67 \pm 0.58$ & $1359.85 \pm 7.41$ & $249.33 \pm 7.51$ \\
$45 \%$ FFEM & $7.62 \pm 0.01$ & $2.87 \pm 0.06$ & $1402.00 \pm 4.00$ & $20.00 \pm 1.00$ & $1377.44 \pm 4.55$ & $298.33 \pm 8.74$ \\
$50 \%$ FFEM & $7.84 \pm 0.01$ & $2.72 \pm 0.40$ & $1428.00 \pm 6.56$ & $24.33 \pm 0.58$ & $1396.33 \pm 7.51$ & $354.00 \pm 9.17$ \\
$55 \%$ FFEM & $7.74 \pm 0.02$ & $2.80 \pm 0.10$ & $1495.00 \pm 4.58$ & $27.00 \pm 1.00$ & $1455.00 \pm 6.56$ & $393.00 \pm 4.00$ \\
$60 \%$ FFEM & $7.75 \pm 0.02$ & $2.87 \pm 0.06$ & $1515.67 \pm 8.02$ & $31.67 \pm 0.58$ & $1479.14 \pm 6.37$ & $438.33 \pm 7.09$ \\
$1.5 \%$ SFWM & $7.65 \pm 0.04$ & $2.77 \pm 0.06$ & $1249.00 \pm 7.00$ & $20.33 \pm 1.15$ & $1224.00 \pm 3.00$ & $252.67 \pm 5.51$ \\
$2.0 \%$ SFWM & $7.71 \pm 0.04$ & $2.70 \pm 0.10$ & $1368.00 \pm 7.55$ & $25.33 \pm 0.58$ & $1331.33 \pm 6.43$ & $312.33 \pm 5.51$ \\
$2.5 \%$ SFWM & $7.78 \pm 0.02$ & $2.93 \pm 0.06$ & $1446.33 \pm 7.02$ & $33.67 \pm 1.15$ & $1408.33 \pm 7.09$ & $349.00 \pm 8.19$ \\
$3.0 \%$ SFWM & $7.82 \pm 0.02$ & $2.87 \pm 0.15$ & $1573.00 \pm 8.54$ & $38.00 \pm 1.00$ & $1523.67 \pm 7.51$ & $397.00 \pm 8.54$ \\
KM & $8.17 \pm 0.02$ & $2.87 \pm 0.06$ & $967.73 \pm 3.42$ & $7.67 \pm 1.15$ & $957.24 \pm 0.96$ & \\
\hline
\end{tabular}

up which was used by the microalgae as the source of nutrients. Similarity was found in
After the culture of $C$. ellipsoidea in the different media under the present study, the 
Table VIII. Mean ( \pm SD) Chemical contents (mg/l, except pH) determined in different concentration of FFEM, SFWM and BBM media before inoculation of $C$. ellipsoidea and S. obliquus

\begin{tabular}{l|c|c|c|c|c|c}
\hline Media & $\mathrm{pH}$ & $\mathrm{DO}$ & $\mathrm{TS}$ & $\mathrm{TSS}$ & TDS & COD \\
\hline $40 \%$ FFEM & $7.08 \pm 0.06$ & $3.17 \pm 0.06$ & $332.59 \pm 2.48$ & $14.44 \pm 1.17$ & $316.48 \pm 2.50$ & $916.33 \pm 5.51$ \\
$45 \%$ FFEM & $7.03 \pm 0.02$ & $3.00 \pm 0.10$ & $373.96 \pm 3.97$ & $16.13 \pm 1.46$ & $356.13 \pm 3.40$ & $1048.67 \pm 7.02$ \\
$50 \%$ FFEM & $7.05 \pm 0.03$ & $3.03 \pm 0.06$ & $416.00 \pm 4.08$ & $17.86 \pm 1.60$ & $395.53 \pm 3.48$ & $1170.33 \pm 6.66$ \\
$55 \%$ FFEM & $7.04 \pm 0.02$ & $3.10 \pm 0.10$ & $457.62 \pm 4.47$ & $19.70 \pm 1.73$ & $435.21 \pm 3.92$ & $1305.33 \pm 9.06$ \\
$60 \%$ FFEM & $7.06 \pm 0.03$ & $2.97 \pm 0.12$ & $503.47 \pm 5.96$ & $21.45 \pm 1.96$ & $475.03 \pm 4.28$ & $1424.33 \pm 6.51$ \\
$1.5 \%$ SFWM & $7.08 \pm 0.05$ & $3.30 \pm 0.10$ & $511.00 \pm 4.58$ & $12.00 \pm 1.00$ & $495.67 \pm 3.21$ & $968.67 \pm 7.02$ \\
$2.0 \%$ SFWM & $7.11 \pm 0.02$ & $3.47 \pm 0.15$ & $603.67 \pm 7.51$ & $15.67 \pm 0.58$ & $582.33 \pm 6.66$ & $1053.67 \pm 6.66$ \\
$2.5 \%$ SFWM & $7.11 \pm 0.03$ & $3.47 \pm 0.12$ & $695.33 \pm 9.07$ & $18.33 \pm 0.58$ & $669.33 \pm 5.69$ & $1142.67 \pm 4.51$ \\
$3.0 \%$ SFWM & $7.13 \pm 0.07$ & $3.33 \pm 0.06$ & $797.33 \pm 9.61$ & $22.33 \pm 1.53$ & $771.33 \pm 7.51$ & $1238.00 \pm 8.19$ \\
BBM & $7.04 \pm 0.03$ & $3.37 \pm 0.15$ & $867.28 \pm 2.52$ & $2.88 \pm 0.52$ & $861.04 \pm 4.60$ & \\
\hline
\end{tabular}

average range of $\mathrm{pH}$ and $\mathrm{DO}$ was recorded 6.85 (in $50 \%$ FFEM) to 6.97 (in $60 \%$ FFEM) and 2.63 (in $1.5 \%$ SFWM) to 3.93 $\mathrm{mg} / \mathrm{l}$ (in BBM), respectively. The average TS were recorded 124.33 to $269.67 \mathrm{mg} / \mathrm{l}$ in different concentrations of the media including the control BBM. The range of TSS was recorded 4.55 (in $\mathrm{BBM}$ ) to $15.67 \mathrm{mg} / \mathrm{l}$ (in $3.0 \%$ SFWM) and TDS was recorded 114.33 (1.5 \% SFWM) to $341.00 \mathrm{mg} / \mathrm{l}$ (55 \% FFEM) for all the treatments (Table IX).

After the culture of $S$. obliquus the range of DO and $\mathrm{pH}$ was recorded 2.57 (in $2.0 \%$

Table IX. Mean ( \pm SD) Chemical contents (mg/l, except $\mathbf{p H})$ determined in different concentration of FFEM, SFWM, and BBM media after culture of $C$. ellipsoidea

\begin{tabular}{l|c|c|c|c|c|c}
\hline Media & $\mathrm{pH}$ & $\mathrm{DO}$ & $\mathrm{TS}$ & TSS & TDS & COD \\
\hline $40 \%$ FFEM & $6.94 \pm 0.03$ & $3.17 \pm 0.15$ & $127.27 \pm 1.97$ & $5.66 \pm 0.52$ & $121.65 \pm 1.52$ & $217.67 \pm 5.51$ \\
$45 \%$ FFEM & $6.91 \pm 0.02$ & $3.63 \pm 0.06$ & $142.29 \pm 2.02$ & $6.35 \pm 1.11$ & $136.25 \pm 2.09$ & $249.33 \pm 6.11$ \\
$50 \%$ FFEM & $6.86 \pm 0.03$ & $3.87 \pm 0.06$ & $158.33 \pm 2.08$ & $7.29 \pm 0.97$ & $155.09 \pm 2.41$ & $292.00 \pm 4.58$ \\
$55 \%$ FFEM & $6.85 \pm 0.03$ & $3.47 \pm 0.06$ & $173.69 \pm 2.52$ & $7.70 \pm 0.61$ & $168.61 \pm 2.56$ & $341.00 \pm 6.56$ \\
$60 \%$ FFEM & $6.97 \pm 0.02$ & $3.43 \pm 0.06$ & $187.89 \pm 3.52$ & $8.27 \pm 0.93$ & $185.35 \pm 2.93$ & $376.33 \pm 5.51$ \\
$1.5 \%$ SFWM & $6.87 \pm 0.06$ & $2.63 \pm 0.12$ & $124.33 \pm 2.08$ & $6.00 \pm 1.00$ & $114.33 \pm 2.52$ & $166.67 \pm 5.51$ \\
$2.0 \%$ SFWM & $6.89 \pm 0.02$ & $2.80 \pm 0.17$ & $166.00 \pm 2.66$ & $9.33 \pm 0.58$ & $153.67 \pm 2.52$ & $195.67 \pm 5.03$ \\
$2.5 \%$ SFWM & $6.84 \pm 0.03$ & $2.77 \pm 0.15$ & $218.00 \pm 3.61$ & $13.33 \pm 1.53$ & $201.67 \pm 4.04$ & $230.67 \pm 4.51$ \\
$3.0 \%$ SFWM & $6.92 \pm 0.03$ & $2.70 \pm 0.17$ & $269.67 \pm 2.52$ & $15.67 \pm 1.15$ & $251.00 \pm 3.00$ & $259.33 \pm 3.51$ \\
BBM & $6.92 \pm 0.01$ & $3.93 \pm 0.12$ & $124.55 \pm 1.49$ & $4.55 \pm 0.50$ & $117.61 \pm 2.11$ & \\
\hline
\end{tabular}


SFWM) to $3.30 \mathrm{mg} / \mathrm{l}$ (in $40 \%$ FFEM) and 6.66 (in $2.0 \%$ SFWM) to 6.85 (in BBM), respectively for all the treatments. The highest average COD was recorded 338.67 $\mathrm{mg} / \mathrm{l}$ in $60 \%$ FFEM and the lowest COD was recorded $131.67 \mathrm{mg} / \mathrm{l}$ in $1.5 \%$ SFWM. The highest average TS was found $277.00 \mathrm{mg} / \mathrm{l}$ in $3.0 \%$ SFWM and the lowest TS was recorded $147.67 \mathrm{mg} / \mathrm{l}$ in $1.5 \%$ SFWM. On the other hand, the range of TSS was recorded 4.67 (in BBM) to $15.67 \mathrm{mg} / \mathrm{l}$ (in $3.0 \% \mathrm{SFWM}$ ) and the range of TDS was recorded 142.00 (in $40 \%$ FFEM) to $262.00 \mathrm{mg} / \mathrm{l}$ (in $3.0 \%$ SFWM). The findings are shown in the Table $\mathrm{X}$.

Table X. Mean ( \pm SD) Chemical contents (mg/l, except $\mathrm{pH}$ ) determined in different concentration of FFEM, SFWM, and BBM after culture of $S$. obliquus

\begin{tabular}{l|c|c|c|c|c|c}
\multicolumn{7}{c}{ tion of FFEM, SFWM, and BBM after culture of $\boldsymbol{S}$. obliquus } \\
\hline Media & $\mathrm{pH}$ & $\mathrm{DO}$ & $\mathrm{TS}$ & $\mathrm{TSS}$ & $\mathrm{TDS}$ & $\mathrm{COD}$ \\
\hline $40 \%$ FFEM & $6.74 \pm 0.03$ & $3.30 \pm 0.20$ & $153.00 \pm 5.57$ & $7.33 \pm 1.53$ & $142.33 \pm 3.06$ & $171.33 \pm 6.51$ \\
$45 \%$ FFEM & $6.80 \pm 0.04$ & $2.83 \pm 0.12$ & $169.67 \pm 4.16$ & $8.00 \pm 1.00$ & $157.67 \pm 4.04$ & $205.00 \pm 6.56$ \\
$50 \%$ FFEM & $6.80 \pm 0.03$ & $3.13 \pm 0.21$ & $187.00 \pm 4.58$ & $9.00 \pm 1.73$ & $170.00 \pm 2.65$ & $255.00 \pm 7.56$ \\
$55 \%$ FFEM & $6.81 \pm 0.09$ & $3.17 \pm 0.21$ & $205.67 \pm 6.11$ & $9.67 \pm 0.58$ & $193.67 \pm 6.51$ & $302.00 \pm 6.56$ \\
$60 \%$ FFEM & $6.84 \pm 0.04$ & $2.83 \pm 0.12$ & $224.67 \pm 6.11$ & $10.00 \pm 1.00$ & $210.67 \pm 6.51$ & $338.67 \pm 5.03$ \\
$1.5 \%$ SFWM & $6.76 \pm 0.05$ & $2.80 \pm 0.10$ & $147.67 \pm 5.03$ & $7.33 \pm 0.58$ & $142.67 \pm 3.21$ & $131.67 \pm 5.51$ \\
$2.0 \%$ SFWM & $6.66 \pm 0.03$ & $2.57 \pm 0.12$ & $186.33 \pm 5.51$ & $10.67 \pm 1.15$ & $176.67 \pm 2.31$ & $159.00 \pm 7.55$ \\
$2.5 \%$ SFWM & $6.79 \pm 0.06$ & $2.83 \pm 0.12$ & $214.33 \pm 3.51$ & $15.33 \pm 1.15$ & $195.33 \pm 3.06$ & $199.33 \pm 8.74$ \\
$3.0 \%$ SFWM & $6.73 \pm 0.02$ & $2.83 \pm 0.21$ & $277.00 \pm 5.57$ & $15.67 \pm 1.53$ & $262.00 \pm 2.65$ & $228.33 \pm 7.51$ \\
BBM & $6.85 \pm 0.13$ & $2.63 \pm 0.15$ & $156.67 \pm 1.53$ & $4.67 \pm 0.58$ & $157.00 \pm 2.65$ & \\
\hline
\end{tabular}

After the culture of $C$. ellipsoidea and $S$. obliquus the amount of TS, TSS, TDS and COD were recorded very lower $(\mathrm{P}<0.05)$ in each media than before culture. It might be due to the biodegradation of organic and inorganic loads and nutrient released in the system, which was used by the microalgae (Islam et al., 2004). Both pH and DO of the media were in favorable condition (Karmaker et al., 2001). Though the growth performance of the algae were lower than control media but it was at the satisfactory level and the algae were nutritionally rich (Habib, 1998; Karmaker et al., 2001 and Islam et al., 2004). Change in all the chemical parameters of the waste media after culture of microalgae had become more or less environment friendly condition.

\section{Conclusion}

The study proved that both fertilizer factory effluent and sweetmeat factory waste media become environment friendly condition after 
culture of microalgae. On the other hand it may possible to use fertilizer factory effluent for commercial culture of $S$. platensis, $C$. ellipsoidea and $S$. obliquus which also may play an important role in aquaculture or as human food and thus the environment will be free from pollution partially.

\section{Acknowledgement}

The authors are indebted to the Director, Bangladesh Agricultural University Research System (BAURES), Bangladesh Agricultural University, Mymensingh, Bangladesh for providing the fund for successful completion of the research.

\section{References}

Clesceri, L.S. Greenberg, A.E. and Trussell, R.R. (1989) Standard Methods for the Examination of Water and Wastewater. American Public Health Association, American Water Works Association and Water Pollution Control Federation; New York. USA, pp. 92-1110.

Habib, M.A.B. Yusoff, F.M. Phang, S.M. Ang, K.J. and Mohamed S. (1997) Nutritional values of chironomid larvae grown in palm oil mill effluent and algal culture. Aquaculture, 158 : 95-105.

Habib, M.A.B. Culture of selected microalgae in rubber and palm oil effluents and their use in the production of enriched rotifers. Doctoral
Thesis, University of Putra. Malaysia, $532 \mathrm{pp}$.

Habib, M.A.B. Yusoff, F.M. Phang, S.M. Kamarudin, M.S. and Mohamed S. (1998). Chemical characteristics and essential nutrients of agroindustrial effluents in Malaysia. Asian Fish. Sci, 11 : 279-286.

Husain, M.I. (2001) Study on the growth performance of Chlorella elipsoidea in various concentrations of jackfruit seed powder medium. M.S. Thesis. Department of Fisheries Management, Bangladesh Agricultural University, Mymensingh, Bangladesh, PP. 36-55.

Islam, M.R. Habib, M.A.B. Miah, M.I. and Khan, A.N.M.A.I. (2004) Growth performance and organic nutrients of chlorella ellipsoidea grown in cabbage powder media. J. Asiat. Soc. Bangladesh Sci. 30(1): 71-78.

Karmaker, P.K. Shajahan, M. Miah, M.I. and Habib, M.A.B. (2001) Culture of microalgae (Chlorella ellipsoidea) in various concentrations of ripe and unripe bean seed powder media. Bangladesh J. Fish. 24(1-2) : 093-99.

Phang, S.M. and Chu, W.L. (1999) Algae culture collection, catalogue of strains. Institute of Postgraduate Studies \& Research, University of Malaya, Kuala Lumpur, Malaysia, 77 pp. 
Phang, S.M. (1990) Algal production from agroindustrial and agricultural wastes in Malaysia. Ambio, 19(8) : 415-418.

Wing-Keong, NG and Chong, K-K. (2002) The nutritive value of Palm Kernal Meal and the Effect of Enzyme Supplementation in Practical Diets for Red Hybrid Tilapia (Oreochromis sp.) Asian Fish. Sci. 15 : 167-176.
Zarouk, C. (1996) Contribution a Letude d une Cyano-phycee de Divers Facteurs Physique et Chimiques sur la Croissane et Photosynthese de Spirulina maxima Geitler, Ph.D. Thesis, University of Paris, France, pp. 45-47.

Received : May 03, 2007;

Accepted : July 01, 2007 